Vol. 2 No. 1 (2019)

\title{
KERJA SAMA PEMBERANTASAN PENDANAAN TERORISME DI ASIA TENGGARA
}

\author{
Max Fredrik Leatemia \\ Departemen Ilmu Hubungan Internasional, Fakultas Ilmu Sosial dan Ilmu Politik \\ Universitas Indonesia \\ maxfredrik615@gmail.com
}

\begin{abstract}
This paper analyzes regional cooperation on Counter Terrorism Financing (CTF) among Southeast Asian countries. Various studies have discussed the factors that construct the response of Southeast Asian countries in fighting terrorism, along with factors that undermines the counter terrorism efforts in the region. Nevertheless, these studies have not specifically adrress the risk of terrorism financing that remains high in the Southeast Asia, particularly in the frame of regional cooperation. By using the Regional Security Complex theory, this paper will explain the polarity and social structure characterizing CTF cooperation in the Southeast Asia, as well as another influential external actor. The focus of this research is on the funding aspects of dominant transnational terrorist groups after September 2001 such as Al-Qaeda and Islamic State (IS). Therefore, the discussion in this research will be focused on five countries that faced the threat of those group, i.e. Indonesia, Philippines, Malaysia, Singapore and Thailand. The findings in this article show that the characteristic of CTF cooperation in the region is largely affected by external power, while the social structure between the internal units of the region is not dominant. Thus, the efforts of the countries become ineffective in overcoming the problem of terrorism financing in the region.
\end{abstract}

Keywords: Southeast Asia, Regional Cooperation, Terrorism Financing, Regional Security Complex (RSC)

Abstrak

Tulisan ini menganalisis kerja sama regional di bidang pemberantasan pendanaan terorisme (PPT) antara negara-negara Asia Tenggara. Berbagai kajian sebelumnya telah membahas faktor-faktor yang mengkonstruksi respon negara-negara Asia Tenggara terhadap terorisme, beserta faktor-faktor yang menghambat upaya kontra terorisme di kawasan. Kendati demikian, kajian-kajian tersebut belum secara spesifik menjawab permasalahan pendanaan terorisme yang masih tinggi di Asia Tenggara, khususnya yang berkaitan dengan upaya regional untuk menanggulangi isu tersebut. Dengan menggunakan teori Regional Security Complex, tulisan ini akan menjelaskan polaritas serta struktur sosial yang membentuk karakteristik kerja sama PPT antar unitunit di kawasan Asia Tenggara, maupun dengan aktor eksternal lainnya. Fokus dari penelitian ini adalah pada aspek pendanaan dari kelompok - kelompok teroris transnasional yang aktif paska Serangan September 2001 seperti Al-Qaeda dan Islamic State (IS). Oleh karena itu, pembahasan mengenai upaya PPT di Asia Tenggara pun akan difokuskan pada lima negara yang menghadapi ancaman dari kelompok-kelompok 
tersebut, yakni Indonesia, Filipina, Malaysia, Singapura dan Thailand. Temuan tulisan ini menunjukkan bahwa karakteristik kerja sama PPT di kawasan Asia Tenggara lebih dipengaruhi oleh kekuatan eksternal kawasan, sementara struktur sosial antar unit-unit internal kawasan tidak dominan. Kondisi ini pada akhirnya membuat kerja sama antar negara-negara Asia Tenggara tidak efektif untuk mengatasi pendanaan terorisme di kawasan.

Kata Kunci: Asia Tenggara, Kerja Sama Regional, Pendanaan Terorisme, Regional Security Complex (RSC)

\section{Pendahuluan}

Perkembangan terorisme di level nasional, regional maupun internasional menunjukkan adanya kecenderungan pola dan strategi serangan yang semakin berkembang dan beradaptasi dengan fenomena global. Eksistensi kelompok terorisme ini tentunya turut ditopang oleh aspek pendanaan yang terorganisir guna membiayai berbagai bentuk kegiatan seperti membeli senjata dan logistik, mengadakan pelatihan, hingga merencanakan serta mengeksekusi serangan. Pendanaan merupakan 'aliran darah' yang perlu diputus untuk menghentikan rantai kegiatan terorisme (Kiser, 2005). Seiring adanya interkoneksitas dan perkembangan teknologi finansial, pendanaan kelompok terorisme tidak lagi terbatas dalam batas-batas yurisdiksi suatu negara, tetapi dapat melintasi batas negara. Oleh karena itu, dibutuhkan kerja sama antar negara-negara di dunia untuk merespon ancaman pendanaan terorisme secara efisien dan efektif.

$$
\text { Konvensi Internasional }
$$

Pemberantasan Pendanaan Terorisme tahun 1999 mengatur bahwa yang dimaksud dengan 'dana' dalam tindak pidana pendanaan terorisme (TPPT) meliputi berbagai macam aset, dokumen-dokumen atau instrumeninstrumen hukum dalam bentuk apapun, termasuk dalam bentuk elektronik atau digital. Secara praktis, dana bukan merupakan tujuan melainkan sarana dalam TPPT. Wujud dana tersebut dapat berupa uang, senjata, bahan peledak, buku-buku, kendaraan, rumah / tempat tinggal dan hal lainnya yang dapat digunakan untuk kepentingan terorisme.

Secara global, berbagai ketentuan yang dikeluarkan oleh Financial Action Task Force (FATF) menjadi standar yang mengatur upaya negara-negara di dunia dalam melawan pendanaan terorisme. ${ }^{1}$ Peran FATF awalnya hanya ditujukan untuk melawan masalah pencucian uang, namun pasca serangan teroris terhadap gedung WTC di Amerika Serikat pada tahun 2001, mandat dari organisasi ini diperluas hingga turut mencakup masalah pendanaan terorisme. Sejak tahun 2011, FATF telah mengeluarkan 9 poin rekomendasi khusus terkait rezim Counter Terrorism Financing / CTF (Pemberantasan Pendanaan Terorisme / PPT) untuk melengkapi 40 rekomendasi terkait rezim Anti Money Laundering / AML (Anti Pencucian Uang / APU) yang telah ada sejak tahun 1990.

FATF juga mengeluarkan daftar Non-Cooperative Countries or

\footnotetext{
${ }^{1}$ FATF dibentuk oleh negara-negara G7 dalam pelaksanaan KTT G7 di Paris untuk melawan kejahatan pencucian uang.
} 
territories (NCCTs) atau yang lebih dikenal sebagai Daftar Hitam (FATF Blacklist) berisi negara-negara yang dinilai kurang kooperatif atau tidak mampu menjalankan ketentuan FATF. Meskipun rekomendasi dan daftar sanksi tersebut tidak memiliki yurisdiksi internasional, namun negara-negara yang masuk dalam daftar hitam tersebut kerap kali mengalami tekanan secara finansial dari anggota-anggota FATF. Hingga saat ini, FATF telah beranggotakan 38 negara dan dua organisasi regional, serta delapan associates members yang mengadopsi model FATF di level regional. (Hayes, 2012)

Dalam konteks Asia Tenggara, negara-negara di kawasan telah mengambil sejumlah inisiatif untuk melawan pendanaan terorisme, antara lain melalui ASEAN Regional Forum $(A R F)$ Statement on Measures Against Terrorist Financing di Brunei Darussalam tahun 2002. Dalam forum tersebut, disebutkan bahwa seluruh anggota ASEAN berkomitmen untuk bekerja sama melawan terorisme dengan tetap berkoordinasi dengan beberapa organisasi internasional lainnya. Selain itu, negara-negara Asia Tenggara juga telah mengadopsi berbagai ketentuan yang ditetapkan oleh International Financial Institutions (IFIs), The Financial Action Task Force on Money Laundering (FATF) dan Financial Stability Forum (FSF) yang berkaitan dengan upaya pendanaan terorisme. Berbagai ketentuan tersebut merupakan strategi kontra terorisme negara-negara anggota ASEAN dengan fokus pada pembekuan aset kelompok teroris. Selain itu, untuk mengontrol kebijakan ini, ARF setiap tahun mengadakan pertemuan untuk mengevaluasi perkembangan upaya dalam melawan pendanaan terorisme, serta merumuskan strategi bersama untuk dilaksanakan di masa mendatang. Inisiatif serupa juga dilakukan melalui pelaksanaan Counter Terrorism Financing (CTF) Summit yang telah digelar secara tahunan sejak 2015 dengan melibatkan negara-negara mitra dialog seperti Australia, Amerika Serikat, Rusia, dan negara-negara lainnya.

Terlepas dari berbagai upaya kerja sama yang dilakukan oleh negaranegara di Asia Tenggara tersebut, penilaian Regional Risk Assessment (RRA) yang dihasilkan dalam pelaksanaan CTF Summit 2016 di Bali menunjukkan bahwa negara-negara Asia Tenggara masih memiliki resiko yang tinggi dalam hal pendanaan terorisme. RRA tahun 2016 pun mengidentifikasi empat tren sumber pendanaan teroris yang dominan di kawasan (AUSTRAC, 2016). Pertama, pendanaan melalui kegiatan bisnis yang legal (legitimate). Kedua, pendanaan melalui organisasi non-profit (NPO) seperti badan amal. Ketiga, penggalangan dana melalui media sosial, website radikal dan jaringan komunikasi (crowdfunding). Keempat, pengumpulan dana melalui aktivitas kriminal seperti pembajakan, perampokan dan sebagainya. Di samping sumber pendanaan, aspek pergerakan uang dan aset kelompok teroris yang melewati batas-batas fisik di dalam kawasan juga masih rentan terjadi. Dengan demikian, kerja sama antar institusi lintas negara masih perlu ditingkatkan (AUSTRAC, 2016).

Untuk itu, rumusan masalah yang akan dibahas oleh penulis dalam artikel ini adalah, "mengapa resiko pendanaan 
terorisme di negara-negara Asia Tenggara masih tinggi meskipun sudah ada berbagai inisisatif kerja sama regional untuk menangani masalah ini?" Artikel ini diharapakan dapat menawarkan alternatif analisis dalam mengkaji upaya melawan ancaman pendanaan terorisme di kawasan. Seiring semakin berkembangnya gelombang radikalisme dan ektrimisme global, perkembangan terorisme telah menjadi salah satu fokus kajian dalam studi keamanan di Asia Tenggara. Namun, kajian yang secara khusus membahas aspek pendanaan terorisme di kawasan ini masih minim, serta tidak disertai kerangka analisis yang memadai.

Kajian terdahulu tentang kerja sama kontraterorisme di Asia Tenggara umumnya mengkaji kerja sama tersebut melalui tiga sudut pandang utama, yaitu (1) sudut pandang historis, (2) sudut pandang politik-ekonomi dan (3) politik-keamanan. Kajian yang menggunakan sudut pandang historis melihat adanya pengaruh warisan pemikiran pasca-kolonial di antara negara-negara ASEAN sehingga cenderung bersikap individual dalam merespon jaringan global terorisme (Desker, 2003). Kajian yang menggunakan sudut pandang politikekonomi berpendapat bahwa upaya negara-negara Asia Tenggara dalam melawan akar terorisme harus dilakukan melalui pembangunan ekonomi dan demokratisasi (Kivimaki, 2007). Sementara kajian yang menggunakan sudut pandang politik-keamanan membahas respon terhadap terorisme di Asia Tenggara dari sisi struktur birokrasi (Jones \& Smith, 2002), sekuritisasi (Sundararaman, 2002; Amitav \& Arabinda Acharya, 2007;
Renwick, 2007; Mustapha, 2011), perimbangan keamanan (Capie, 2004), dan keamanan komprehesif kawasan (Swanstrom \& Bjornehed, 2004; Emmers, 2009; Singh, 2009). Setidaknya ada dua isu utama yang muncul dalam kelompok kajian politikkeamanan. Pertama, respon negaranegara Asia Tenggara terhadap terorisme tidak dapat dipisahkan dari pengaruh pendekatan 'war on terror' Amerika Serikat. Kedua, pentingnya pendekatan struktural dan institusional di kawasan dalam merespon terorisme.

Berbagai kajian di atas telah membahas faktor-faktor yang mengkonstruksi respon negara-negara Asia Tenggara terhadap terorisme, beserta faktor-faktor yang menghambat upaya kontra terorisme di kawasan. Kendati demikian, kajian-kajian tersebut belum secara spesifik menjawab permasalahan pendanaan terorisme yang masih tinggi di Asia Tenggara, khususnya yang berkaitan dengan upaya regional untuk menanggulangi isu tersebut. Sebagai pembanding, ada ketimpangan antara kajian akademis tentang kerja sama melawan pendanaan terorisme di Asia Tenggara dengan wilayah lainnya seperti Uni Eropa (Vicek, 2009; Bures, 2010; Kaunert \& Giovanna, 2010; Bures, 2015) maupun Transatlantik (Kingah \& Zwartjes, 2015).

\section{Metode Penelitian}

Penulis akan menggunakan Teori Regional Security Complex (RSC) sebagai kerangka analisa untuk menjawab pertanyaan yang diangkat dalam tulisan ini. Penulis akan terlebih dahulu membahas tentang variabelvariabel utama dari RSC serta pengaruhnya terhadap dinamika 
keamanan di kawasan Asia Tenggara, termasuk dalam hal respon negaranegara Asia Tenggara atas isu terorisme. Selanjutnya, tulisan ini akan menggambarkan tentang upaya-upaya yang telah dilakukan oleh negara-negara Asia Tenggara serta Australia sebagai unit eksternal yang memiliki pengaruh besar dalam melawan pendanaan terorisme di level regional maupun global. Dengan menggunakan data-data tersebut, tulisan ini pada akhirnya akan menjelaskan mengenai polaritas dan interaksi sosial yang mewarnai kerja sama CTF antara negara-negara Asia Tenggara, serta dampaknya terhadap efektifitas kerja sama tersebut di internal kawasan.

\section{Regional Security Complex}

Security complex pada awalnya didefinisikan oleh Buzan dan Waever sebagai sekumpulan negara yang persepsi dan fokus keamanan utamanya saling berkaitan sehingga masalah keamanannya tidak dapat dianalisa atau diatasi secara terpisah (Buzan, 1997). Pada tahun 2003, konsep regional security complex ini didefinisikan ulang sebagai sekumpulan unit yang samasama mengalami proses sekuritisasi, desekuritisasi, ataupun keduanya. Interdependensi antar unit tersebut menyebabkan masalah keamanan negara-negara tersebut tidak dapat dianalisa secara terpisah satu sama lain (Buzan \& Waefer, 2003). Negaranegara dalam suatu kawasan keamanan (RSC) akan berupaya untuk mengelola keamanannya melalui kerja sama dengan negara-negara di kawasan demi mengupayakan keteraturan dan keamanan regional. Kendati demikian, hubungan kerja sama dan saling ketergantungan antar negara-negara dalam RSC tidak serta-merta menghilangkan bentuk persaingan, perimbangan kekuasaan, atau bahkan pengaruh kekuatan eksternal yang dapat memunculkan konflik di antara mereka. (Buzan \& Waefer, 2003)

Dalam mengkaji suatu kawasan keamanan, seorang peneliti perlu menggunakan 4 level analisis. Level analisis yang pertama adalah level domestik (domestic level). Pada tingkatan ini peneliti perlu mengkaji situasi internal yang dialami oleh masing-masing negara yang ada di kawasan, kekuatan dan kerawanan mereka di tingkat domestik serta dampaknya dari sisi stabilitas keamanan. Level analisis yang kedua yaitu hubungan antar negara di dalam RSC (state - to - state relations). Pada tingkatan ini kajian difokuskan pada relasi antar negara-negara yang ada di dalam kawasan serta keterkaitan aspek keamanan diantara mereka. Level analisis yang ketiga yaitu interaksi kawasan tersebut dengan kawasan lain di sekitarnya (regions's interaction with neighbouring regions). Pada tingkatan ini peneliti perlu mengkaji apakah ada bentuk relasi dengan kawasan tetangga yang mempengaruhi masalah keamanan di suatu kawasan. Relasi dengan kawasan sekitar ini seharusnya hanya memiliki pengaruh yang terbatas mengingat karakteristik sebuah kawasan keamanan lebih dipengaruhi oleh interaksi internalnya. Level analisis yang keempat yaitu peran kekuatan global di kawasan (the role of global powers in the region) - pada tingkatan ini, peneliti mengkaji hubungan antara struktur keamanan global dan regional yang saling mempengaruhi.

Selain keempat level analisis tersebut, ada empat variabel yang membentuk struktur utama sebuah 
kawasan keamanan. Pertama, batas wilayah (boundary) yang secara geografis membedakan suatu kawasan keamanan dengan kawasan lain di sekitarnya. Kedua, struktur anarki (anarchic structure) yang terdiri dari minimal 2 unit otonom. Ketiga, polaritas (polarity) yang berkaitan dengan distribusi kekuatan antar unit. Sebagai sub-struktur dalam sistem internasional, relasi kekuatan dalam RSC dapat dikaji dengan melihat polaritas kekuatan global dan regional (unipolar, bipolar, multipolar), serta interaksi dan distribusi kekuatan baik antara sesama kekuatan domestik (dalam kawasan) maupun antara aktor domestik dengan kekuatan global lainnya di luar kawasan. Keempat, struktur sosial (social construction) yaitu pola pertemanan dan permusuhan antar unit yang dapat dikaji dari faktorfaktor seperti sejarah, budaya, agama, kondisi geografis, dan berbagai faktor sosial lainnya. Dua variabel pertama yaitu batas wilayah dan struktur anarki merupakan fitur alami yang selalu melatar belakangi berbagai kerja sama keamanan antara negara-negara Asia Tenggara. Sementara itu, dua variabel terakhir (polaritas serta struktur sosial) lebih bersifat dinamis dan akan sangat berpengaruh terhadap karakter utama sebuah kawasan keamanan.

Pada dasarnya setiap negara dalam sistem global mengalami interdependensi keamanan dengan negara lain. Namun karena ancaman politik dan keamanan cenderung lebih mudah menyebar dalam jarak dekat daripada jarak jauh, maka ketidakamanan seringkali dikaitkan dengan aspek kedekatan wilayah (proximity). Konsekuensinya, interdependensi akan lebih menonjol antara negara-negara yang berada dalam suatu kawasan (complex) daripada negara lainnya di luar kawasan (Buzan, Waefer \& Wilde, 1998). Kendati demikian, tidak semua negara yang letaknya berdekatan dapat menjalin suatu pengaturan keamanan bersama. Kedalaman interaksi antar unit juga berperan penting dalam menentukan apakah mereka merasa sebagai satu kesatuan. Meskipun berdekatan secara geografis, namun tingkat interaksi yang rendah dapat membuat negara-negara yang secara fisik berdekatan merasa saling terpisah. Kesamaan sistem ekonomi, politik, sosial dan budaya antar negara-negara juga dapat menumbuhkan rasa solidaritas yang kuat antar aktor dalam suatu kawasan.

Struktur utama suatu kawasan keamanan dapat mengalami evolusi dalam kurun waktu tertentu sejak pembentukannya. Ada tiga macam perubahan yang dapat terjadi dalam struktur suatu kawasan keamanan. Pertama, terjaganya status quo (maintenance of the status quo) yang berarti bahwa tidak ada perubahan signifikan dalam struktur utama RSC. Kedua, transformasi internal (internal transformation) yaitu perubahanperubahan yang terjadi di dalam batas wilayah suatu RSC. Transformasi internal ini dapat berupa (namun tidak terbatas pada) perubahan struktur, polaritas, maupun pola pertemanan/ permusuhan antar unit. Ketiga, transformasi eksternal (external transformation) yang berarti bahwa batas-batas suatu kawasan keamanan mengalami perluasan ataupun penyempitan sehingga merubah keanggotaan RSC, dan kemungkinan besar juga merubah strutur inti RSC. Transformasi eksternal ini dapat terjadi 
ketika dua RSC bergabung menjadi satu, atau ketika sebuah RSC terpecah menjadi dua.

Selain berbagai penjelasan konseptual terkait RSC, Buzan juga mengkaji karakteristik RSC pada berbagai kawasan di dunia, salah satunya yaitu Asia Tenggara (Buzan, 1998). Sebagai sebuah RSC, persepsi keamanan antara negara-negara Asia Tenggara sangat dipengaruhi oleh sejarah perebutan pengaruh antara Blok Barat dan Blok Timur pada masa Perang Dingin. Selain perbedaan ideologi, hubungan sejarah Asia Tenggara juga diwarnai dengan berbagai konflik terkait batas wilayah antar negara. Dalam berbagai konflik politik tersebut, struktur kekuatan di kawasan lebih berifat multipolar dimana tidak ada satu pun negara Asia Tenggara yang dapat dengan mudah mendominasi lingkungan keamanan regional. Di sisi lain, dinamika interaksi yang sangat dominan antara Asia Tenggara dengan kawasan lain di sekitarnya serta negara-negara superpower seperti AS, Tiongkok, dan Rusia menjadi faktor yang menghambat pembentukan komunitas keamanan di internal kawasan. Hal ini misalnya terlihat dari berbagai kendala dalam implementasi ZOPFAN (Zone of Peace, Freedom and Neutrality) yang dipromosikan ASEAN. Dalam pelaksanaannya, negara-negara Asia Tenggara tetap meminta dukungan kekuatan besar dari luar kawasan apabila merasa terancam. Dinamika antara aktor lokal Asia Tenggara dengan kekuatan-kekuatan global ini mengakibatkan selalu terjadinya perpecahan internal, serta penetrasi dari kepentingan aktor-aktor eksternal yang lebih kuat.
Pandangan Buzan mengenai karakteristik RSC di Asia Tenggara ini pada aspek tertentu masih relevan untuk mengkaji dinamika keamanan regional saat ini, sekalipun definisi/ makna keamanan itu sendiri telah diperluas hingga mencakup isu-isu nontradisional seperti terorisme. Secara historis, penanganan terorisme di Asia Tenggara tidak dapat dipisahkan dari kebijakan Amerika Serikat yang menjadikan kawasan ini sebagai second front dalam perang melawan terorisme (Acharya, 2004). Hal ini direpon secara berbeda oleh negara-negara Asia Tenggara. Singapura dan Australia memiliki pandangan yang sama dengan AS bahwa kelompok teroris Islam merupakan ancaman utama terhadap keamanan nasional maupun regional. Sebaliknya, Malaysia dan Indonesia sebagai negara dengan mayoritas penduduk muslim khawatir dengan upaya AS untuk mengasosiasikan terorisme dengan Islam. Bagi kedua negara ini, terorisme merupakan sebuah isu politik yang berkaitan erat dengan dinamika politik domestik. Sementara itu, Thailand lebih melihat berbagai aksi terorisme sebagai tindakan kriminal yang dilakukan oleh kelompok preman dan gangster (Perrin, 2002). Akar pemahaman yang berbeda terhadap terorisme sebagai ancaman keamanan ini menyebabkan adanya perbedaan dalam hal strategi dan jalur yang digunakan oleh negara-negara Asia Tenggara dalam melawan terorisme.

Dalam menjelaskan lebih lanjut mengenai karakteristik kawasan keamanan terkait kerja sama PPT di Asia Tenggara, tulisan ini akan menggunakan metode penelitian kualitatif. Fokus dari penelitian ini adalah terhadap kelompok - kelompok 
teroris transnasional yang aktif paska peristiwa 9/11 seperti Al-Qaeda dan IS. Oleh karena itu, pembahasan mengenai upaya PPT di Asia Tenggara pun akan difokuskan pada lima negara yang menghadapi ancaman dari kelompokkelompok tersebut, yakni Indonesia, Filipina, Malaysia, Singapura dan Thailand.

Penulis akan menggunakan datadata terkait kerjasama PPT di kelima negara Asia Tenggara tersebut sejak tahun 2001 hingga 2017. Data-data tersebut dikumpulkan dari sumbersumber primer berupa laporan-laporan ataupun dokumen-dokumen resmi yang dihasilkan oleh negara-negara di kawasan, misalnya Regional Risk Assessment yang dihasilkan dalam CTF Summit 2016 sebagai acuan untuk menggambarkan bentuk-bentuk ancaman pendanaan terorisme serta berbagai inisiatif regional untuk menanganinya. Selain itu, penulis juga akan menggunakan data-data dari sumber sekunder seperti studi pustaka maupun berbagai publikasi, khususnya dari media daring. Proses triangulasi kemudian akan dilakukan untuk memastikan validitas dan reliabilitas dari data-data tersebut.

\section{Hasil dan Pembahasan}

\section{A. Upaya Negara-Negara Asia Tenggara dalam Melawan Pendanaan Terorisme \\ 1) Indonesia}

Indonesia adalah anggota Asia/Pacific Group on Money Laundering (APG) yang merupakan perpanjangan tangan FATF di level regional. Lembaga FIU di Indonesia yaitu Pusat Pelaporan dan Analisis Transaksi Keuangan (PPATK) juga tergabung dalam Egmont Group. ${ }^{2}$ Sejak tahun 2015, PPATK bersama AUSTRAC (FIU Australia) telah menjadi inisiator pelaksanaan forum tahunan Counterterrorist Financing (CTF) Summit. Indonesia menjadi tuan Rumah CTF Summit ke-2 pada Agustus 2016 di Bali yang dihadiri oleh lebih dari 200 pakar pendanaan terorisme dari 20 negara. Dalam forum ini, Indonesia dan Australia menginisiasi penyusunan Regional Risk Assesment on Terrorist Financing yang untuk pertama kalinya membahas aspek-aspek ancaman pendanaan terorisme di kawasan.

Dari segi legislasi, UndangUndang RI No. 9 tahun 2013 tentang Pencegahan dan Pemberantasan Tindak Pidana Pendanaan Terorisme telah mengatur sanksi terhadap pencucian uang dan pendanaan terorisme, serta mengatur pembekuan aset terorisme sehingga sejalan dengan Resolusi Dewan Keamanan PBB No. 1373 dan Daftar Sanksi DK PBB. Dengan demikian, pemerintah Indonesia memiliki kewajiban untuk membekukan aset milik individu dan entitas yang berkaitan dengan ISIS dan Al Qaeda. Aturan hukum di Indonesia juga mengharuskan organisasi non-profit (NPO) seperti organisasi agama dan lembaga amal untuk mendaftarkan diri serta melaporkan transaksi keuangannya.

Selain itu, otoritas Indonesia telah membuat dan mengembangkan sistem elektronik Daftar Terduga Teroris dan Organisasi Teroris (DTTOT) yang terintegrasi antar lembaga nasional sehingga mempermudah koordinasi dan

\footnotetext{
2 Egmont Group of FIU merupakan sebuah jaringan informal yang beranggotakan 156 badan intelijen keuangan (FIU) dari berbagai negara di dunia.
} 
eksekusi pembekuan aset teroris (Aini, 2017).

\section{2) Malaysia}

Malaysia merupakan anggota APG dan telah menjadi anggota penuh FATF sejak Februari 2016. Lembaga FIU di Malaysia yaitu Unit Perisikan Kewangan, Bank Negara Malaysia juga tergabung dalam keanggotaan Egmont Group. Laporan evaluasi bersama yang dirilis oleh FATF pada tahun 2015 memberikan penilaian yang positif terhadap Malaysia atas komitmen politik dan kerangka kebijakan yang sangat kuat, serta struktur koordinasi yang baik dalam melawan pencucian uang dan pendanaan terorisme. Kendati demikian, laporan tersebut menekankan bahwa pemerintah Malaysia masih perlu meningkatkan pemahaman terkait resiko pendanaan terorisme. Hal ini berkaitan juga dengan penggunaan jasa pengiriman uang tidak resmi (informal remittance) sebagai jalur utama yang sering dimanfaatkan oleh kelompok teroris di Malaysia untuk menyalurkan dananya. Kendati pemerintah telah memperkuat pengawasan dan mendorong masyarakat untuk menggunakan sistem pengiriman uang formal, penggunaan jasa pengiriman tidak resmi ini masih menjadi kerawanan di Malaysia.

Malaysia telah menerapkan sanksi serta pembekuan aset terhadap individu atau entitas teroris yang ditetapkan Resolusi DK PBB No. 1373. Dengan adanya revisi pada tahun 2014 terhadap Undang-Undang Anti Pencucian Uang dan Pendanaan Terorisme Malaysia, maka nama-nama yang berada dalam daftar sanksi PBB secara otomatis masuk ke dalam daftar sanksi Pemerintah Malaysia. Pemerintah Malaysia pun secara rutin mendistribusikan daftar entitas teroris kepada lembaga-lembaga keuangannya agar asetnya dapat dibekukan.

\section{3) Filipina}

Filipina merupakan anggota APG, sementara lembaga intelijen keuangannya yaitu Anti Money Laundering Council (AMLC) merupakan anggota Egmont Group. Pada tahun 2016, pemerintah Filipina untuk pertama kalinya mempublikasikan National Risk Assesment on Money Laundering and Terrorist Financing (2011-2014) yang merupakan hasil kajian lintas lembaga nasional. Pada tahun yang sama, AMLC dan lembaga anti teror lainnya di Filipina bekerja sama dengan berbagai otoritas keamanan asal Amerika Serikat melalui Joint Terrorist Financing Investigation Group untuk melakukan investigasi terhadap aliran dana yang diduga berkaitan dengan kelompok teroris. ${ }^{3}$ Filipina juga telah melaksanakan ketentuan DK PBB terkait sanksi terhadap entitas yang berkaitan dengan ISIS, Al-Qaeda, dan Taliban.

Aktivitas kriminal masih menjadi sumber pendanaan utama bagi individu dan kelompok teroris di Filipina. Para teroris biasanya menyelundupkan uang tunai dengan memanfaatkan kelemahan pengawasan di wilayah perbatasan Filipina, baik melalui darat maupun laut.

\footnotetext{
${ }^{3}$ Selain AMLC, lembaga lainnya di Filipina yang terlibat dalam Joint Terrorist Financing Investigation Group bersama Amerika Serikat yaitu Anti-Terrorism Council, National Police's Directorate of Intelligence, Anti-Kidnapping Group, National Bureau of Investigatons, Philippine Center on Transnational Crime (PCTC), dan Special Action Force.
} 


\section{4) Singapura}

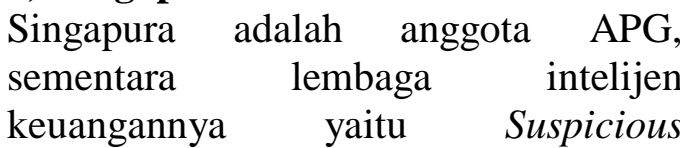
Transaction Reporting Office (STRO) merupakan anggota dari Egmont Group. Berdasarkan laporan evaluasi bersama yang dipublikasikan oleh APG dan FATF pada September 2016, Singapura memiliki legislasi dan kerangka aturan keuangan yang kuat dalam melawan ancaman terorisme. Singapura juga dinilai telah menjalankan pembekuan aset terorisme secara efektif, terlihat dari aset kelompok teroris dengan nilai sekitar 2 juta USD yang telah dibekukan Pemerintah Singapura sejak tahun 20042014. Sebagai salah satu pusat keuangan internasional, pemerintah Singapura dianjurkan untuk terus meningkatkan pemahamannya terhadap resiko pendanaan terorisme, serta memperkuat pengawasan terhadap aliran dana teroris yang melalui organisasi non-profit (NPO). Laporan tersebut juga menganjurkan peningkatan koordinasi antara Departemen Keamanan Internal dan Departemen Perdagangan untuk memastikan dilakukannya investigasi menyeluruh terhadap potensi aliran dana teroris.

\section{5) Thailand}

Thailand merupakan anggota APG, sementara lembaga FIU-nya yaitu AntiMoney Laundering Office (AMLO) merupakan anggota Egmont Group. Undang-undang PPT dan aturan-aturan hukum dibawahnya mulai berlaku efektif pada awal 2013. Pada tahun 2015, AMLO melakukan revisi UU Anti Pendanaan Terorisme sehingga sejalan dengan ketentuan DK PBB terkait sanksi terhadap entitas yang berkaitan dengan ISIS dan Al-Qaeda.
Apabila ada indikasi pengiriman dana secara ilegal, Bank of Thailand akan berkoordinasi dengan Polisi Kerajaan Thailand untuk menangkap pelakunya. Pada tahun 2016, AMLO membekukan aset milik 8 individu atas dasar UU Anti Pendanaan Terorisme milik Thailand.

\section{B. Interaksi dengan Australia sebagai Aktor Eksternal sekaligus Kekuatan Global}

Australia terus memainkan peranan penting sebagai pemimpin dalam upaya melawan pendanaan terorisme, baik di tingkat regional, maupun global (US Department of State, 2017). Australia aktif sebagai anggota FATF dan merupakan wakil ketua FATF's Risks, Trends, and Methods Group. Australia merupakan salah satu pendiri APG serta Wakil Ketua Kelompok Kerja Evaluasi Bersama APG. Badan intelijen keuangan Australia (AUSTRAC) merupakan salah satu pendiri Egmont Group, serta berperan dalam membantu negara-negara Asia Tenggara untuk menyusun profil aliran dana foreign terrorist fighter (FTF) di level regional.

Australia menghadapi beragam ancaman pendanaan terorisme, namun resikonya dapat dilawan dengan kerangka hukum dan administratif yang komprehensif. Pemerintah Australia dapat secara otomatis membekukan daftar aset yang berkaitan dengan terorisme. Selain itu, pemerintah Australia juga secara aktif menerapkan sanksi DK PBB terhadap entitas yang berkaitan dengan ISIS dan Al-Qaeda. Badan Intelijen Keuangan AUSTRAC bekerja sama dengan lembaga-lembaga penegak hukum dalam mendeteksi, mencegah dan melawan aktivitas pencucian uang dan pendanaan terorisme, serta menyusun regulasi 
terkait transfer dana maupun jasa pinjaman. Australia juga berupaya menyusun regulasi terkait penggunaan sistem mata uang virtual seperti Bitcoin, namun jalur pendanaan seperti yayasan amal di Australia tidak termasuk dalam kategori aliran dana mencurigakan.

Pada April 2016, AUSTRAC turut terlibat dalam menyelenggarakan Experts Symposium on Regional Risk of Terrorist Finance di Medan, Indonesia, yang menghasilkan rancangan konsep Regional Risk Assessment on Terrorist Financing. Pada Juni 2016, AUSTRAC bekerja sama dengan badan intelijen keuangan AMLC Filipina menyelenggarakan Regional Risk Assessment Workshop di Manila. Kemudian pada Agustus 2018, AUSTRAC membentuk tim siber untuk mengidentifikasi aktivitas pendanaan terorisme, pencucian uang, serta kejahatan finansial lainnya yang dilakukan secara online. Pada tahun 2016, untuk kedua kalinya Australia menjadi penyelenggara forum $C T F$ Summit yang berlangsung di Bali. Forum ini menghasilkan dokumen Regional Risk Assessment pertama di dunia, yang merupakan tindak lanjut dari pelaksanaan simposium di Medan. Pada November 2016, AUSTRAC mempublikasikan penilaian resiko terkait pendanaan terorisme melalui sektor nirlaba di Australia, yang kemudian diangkat sebagai tema khusus dalam pelaksanaan CTF Summit 2017 di Kuala Lumpur, Malaysia. CTF Summit 2017 ini merupakan hasil kerja sama antara AUSTRAC Australia, PPATK Indonesia, dan Bank Negara Malaysia.

\section{Karakteristik Kawasan Keamanan Asia Tenggara dalam hal Melawan Pendanaan Terorisme}

Karakteristik Asia Tenggara sebagai suatu kawasan keamanan dapat dianalisa dengan menggunakan dua variabel penting dalam RSCT yaitu polaritas dan struktur sosial. Polaritas berkaitan dengan distribusi dan interaksi kekuatan, baik antara sesama kekuatan domestik dalam kawasan, maupun antara aktor domestik dengan kekuatan global lainnya di luar kawasan. Sedangkan struktur sosial berkaitan dengan pola pertemanan dan permusuhan antar unit yang dapat dikaji dari faktor-faktor seperti sejarah, budaya, agama, kondisi geografis, dan berbagai faktor sosial lainnya.

Secara umum, berdasarkan penjelasan-penjelasan sebelumnya, karakteristik kawasan keamanan di Asia Tenggara saat ini tidak banyak mengalami perubahan dari kondisi yang digambarkan oleh Buzan maupun Acharya. Dalam hal upaya melawan pendanaan terorisme, tidak ada kekuatan internal yang cukup dominan diantara negara-negara Asia Tenggara sehingga pengaruh kekuatan eksternal (dalam hal ini Australia) lebih dominan. Faktor-faktor lainnya seperti perbedaan sejarah, budaya, agama dalam struktur sosial negara-negara Asia Tenggara juga menjadi faktor yang mendorong adanya perbedaan persepsi terkait ancaman pendanaan terorisme dan bagaimana meresponnya.

Dinamika kerja sama PPT di Asia Tenggara jelas menunjukkan adanya dominasi kekuatan eksternal di luar kawasan, terutama Australia sebagai kekuatan unipolar (dari RSC lain) yang secara geografis berada paling dekat dengan Asia Tenggara. Hal ini terlihat 
dari keterlibatan Australia sebagai penggagas maupun penggerak (melalui bantuan dana, tenaga ahli, dan sumber daya lainnya) dalam berbagai inisiatif PPT yang utama di Asia Tenggara. Sementara itu, interaksi antara unit-unit internal di Asia Tenggara tidak begitu terlihat sehingga struktur sosialnya tidak dominan.

Secara global, pengaturan kerja sama antar negara dalam hal bantuan pengembangan kapasitas PPT sebagian besar masih bersifat bilateral dan terbatas pada aspek-aspek tertentu saja (The Egmont Group, 2004). Ironisnya, dibandingkan memperkuat kerja sama dengan unit-unit di internal kawasan, negara-negara Asia Tenggara lebih cenderung untuk mengembangkan kerjasama bilateral maupun trilateral dengan kekuatan besar dari luar kawasan. Sebagai contoh, Filipina tidak menjalin kerjasama khusus dengan negara-negara Asia Tenggara di bidang PPT. Kerjasama khusus justru dilakukan Filipina bersama Amerika Serikat melalui Joint Terrorist Financing Investigation Group, maupun melalui penyelenggaraan Regional Risk Assessment Workshop bersama AUSTRAC Australia.

Kecenderungan untuk bekerja sama dengan aktor eksternal seperti Australia tentunya tidak terlepas dari kekuatan / pengaruh negara tersebut sebagai anggota FATF. Padahal kerjasama dengan aktor-aktor besar tersebut tidak serta merta ditujukan untuk menjawab tantangan yang muncul akibat aktivitas pendanaan terorisme. Dalam berbagai kasus, perilaku kerja sama dalam kerangka regulasi FATF tersebut dilakukan negara untuk menghindari tekanan atau ancaman sanksi internasional. Tekanan tersebut pernah dialami Indonesia bersama 16 negara lainnya yang dimasukkan FATF ke dalam daftar sanksi pada Februari 2012 (Kertopati, 2013). Negara-negara dalam daftar sanksi tersebut dinilai masih memiliki kelemahan dalam hal strategi memberantas pendanaan terorisme. Hal serupa juga pernah dialami Indonesia pada tahun 2001 ketika FATF memasukkan Indonesia ke dalam kategori Teritori dan Negara Nonkooperatif (NCCT) dalam upaya global menanggulangi kejahatan pencucian uang. FATF baru menghapus nama Indonesia dari daftar tersebut pada tahun 2005 setelah Pemerintah Indonesia membuat beberapa UU terkait tindak pidana pencucian uang.

Polaritas hubungan antara negaranegara Asia Tenggara dengan aktor besar di luar kawasan ini turut berpengaruh terhadap efektifitas kerja sama dalam melawan pendanaan terorisme di kawasan. Secara keseluruhan, kerja sama dengan para aktor besar ini mampu mengurangi kesenjangan kapasitas di negara-negara Asia Tenggara, namun masih ada berbagai kesenjangan dalam kapasitas yang berkaitan dengan persyaratan teknis dari langkah-langkah APU /PPT (The Egmont Group, 2004). Seluruh negara Asia Tenggara telah menjalankan rekomendasi FATF dalam hal ratifikasi konvensi - konvensi internasional di bidang PPT, serta telah menjalin kerja sama formal di level atas terkait pertukaran informasi. Di sisi lain, pengawasan terhadap lalu lintas pendanaan terorisme melalui perbatasan masih menjadi kesenjangan utama dalam kerja sama di Asia Tenggara (AUSTRAC, 2016).

Bentuk relasi seperti ini membuat kerjasama PPT antar negara-negara di 
kawasan Asia Tenggara menjadi tidak efektif karena tidak secara tepat menjawab dinamika ancaman pendanaan terorisme secara regional. Di samping adopsi norma-norma internasional di level makro, tidak banyak langkah konkrit yang dilakukan oleh negara-negara Asia Tenggara untuk menghadapi aspek-aspek pendanaan terorisme yang berdampak langsung terhadap lingkungan keamanan di kawasan. Sebagai contoh, belum ada upaya kolektif yang benarbenar efektif antara Pemerintah Indonesia, Filipina, dan Malaysia dalam hal pengawasan perbatasan laut mereka yang kerap digunakan sebagai akses para pelaku teror (IPAC, 2019). Padahal pergerakan para teroris melalui batasbatas fisik ketiga negara saat ini merupakan salah satu sumber dan saluran utama pendanaan terorisme di kawasan.

Polaritas hubungan kerjasama yang lebih tinggi terhadap kekuatan besar di luar kawasan juga dapat disebabkan oleh kondisi struktural di level regional maupun level domestik. Dalam menghadapi ancaman pendanaan terorisme, upaya regional di Asia Tenggara lebih cenderung dilakukan melalui deklarasi dan penetapan aturan dibanding membentuk mekanisme PPT yang konkrit secara operasional. Kerja sama yang dilakukan oleh organisasiorganisasi regional masih terfokus pada pertukaran informasi dan intelijen serta pengembangan kapasitas.

Di sisi lain, ada beberapa faktor yang mempersulit terwujudnya kerja sama yang lebih erat antara negaranegara Asia Tenggara, termasuk misalnya perbedaan prioritas dan kepentingan, pertimbangan politik domestik, kecurigaan antar negara, hingga kelemahan dalam hal kapasitas institusional di level domestik. Dalam berbagai kasus, koordinasi antar lembaga negara di level domestik masih menjadi kelemahan dalam upaya PPT, khususnya dalam menghentikan perpindahan dana tunai oleh para teroris melalui perbatasan negara-negara. Sebagai contoh, meskipun Pemerintah Indonesia telah menempatkan petugas Imigrasi di setiap bandara dan pelabuhan besar, namun sistem Advanced Passenger Information dan Passenger Name Record belum sepenuhnya digunakan untuk mendukung pemeriksaan di titik-titik tersebut. Petugas imigrasi juga memiliki akses data kependudukan berbasis biografi maupun biometrik, namun cakupannya hanya untuk penumpang domestik (WNI). Di sisi lain, lembaga penegak hukum seperti Polri memiliki daftar terduga teroris yang berada dalam pengawasan, namun dalam praktiknya alur komunikasi / koordinasi dengan instansi atau stakeholder lainnya tidak selalu berjalan lancar (US Department of States, 2017).

Kelemahan dalam pengawasan perbatasan juga dialami oleh Thailand. Salah satu penyebabnya adalah masifnya penjualan dokumen palsu di sana, meskipun sudah ada berbagai upaya dari pemerintah untuk mengungkap jaringan para pelaku. Dalam upaya untuk mendeteksi para pelaku kejahatan dan pelaku teror, kepolisian Thailand telah menjalin kerja sama sehingga dapat memiliki akses ke sistem pengawasan Interpol. Kendati demikian, petugas Imigrasi yang bertugas langsung dalam melakukan pengawasan di perbatasan belum terkoneksi dengan data tersebut (US Department of States, 2017). 
Vol. 2 No. 1 (2019)

Kelemahan-kelemahan antar unitunit di level domestik ini pada akhirnya menyulitkan negara-negara Asia Tenggara untuk dapat memproyeksikan kekuatan ke level regional, sehingga pengaturan keamanan di kawasan sulit terwujud. Agar dapat mengembangkan kapasitas regional, negara-negara Asia Tenggara sebaiknya turut memberikan perhatian pada bentuk-bentuk kerjasama yang bersifat operasional.

\section{Kesimpulan}

Sebagai sebuah RSC, interaksi keamanan antara negara-negara di Asia Tenggara sangat dipengaruhi oleh sejarah perebutan pengaruh antara kekuatan-kekuatan eksternal. Dalam berbagai konflik politik tersebut, struktur kekuatan di kawasan lebih berifat multipolar dimana tidak ada satu pun negara Asia Tenggara yang dapat dengan mudah mendominasi lingkungan keamanan regional. Di sisi lain, dinamika interaksi yang sangat dominan antara Asia Tenggara dengan kawasan lain di sekitarnya serta negaranegara superpower menjadi faktor yang menghambat pembentukan komunitas keamanan di internal kawasan. Dinamika antara aktor lokal Asia Tenggara dengan kekuatan-kekuatan global ini mengakibatkan selalu terjadinya perpecahan internal, serta penetrasi dari kepentingan aktor-aktor eksternal yang lebih kuat.

Kondisi diatas turut mewarnai kerjasama CTF antar negara-negara Asia Tenggara dimana karakteristik kerjasama CTF di kawasan Asia Tenggara lebih dipengaruhi oleh kekuatan eksternal kawasan, sementara struktur sosial antar unit-unit internal kawasan tidak dominan. Kondisi ini pada akhirnya membuat kerjasama antar negara-negara Asia Tenggara tidak efektif untuk mengatasi ancaman pendanaan terorisme di kawasan. Agar dapat menjawab ancaman pendanaan terorisme di kawasan, negara-negara Asia Tenggara perlu berupaya untuk mengembangkan struktur sosial dan pola interdependensinya sendiri.

\section{DAFTAR PUSTAKA}

Acharya, A. (2004). Terrorism and Security in Asia: Redefining Regional Order. Murdoch University

Acharya, Amitav \& Arabinda (2007). The Myth of the Second Front: Localizing the 'War on Terror' in Southeast Asia. The Washington Quarterly, 30:4, 75-90.

Aini, N. (2017). BI Cegah Uang Elektronik Disusupi Transaksi Teroris. Tersedia di https://www.republika.co.id/berita /ekonomi/keuangan/17/09/13/ow7 xfx382-bi-cegah-uang-elektronikdisusupi-transaksi-teroris. Diakses pada 3 Mei 2019.

AUSTRAC (2016). Terrorism Financing Regional Risk Assessment 2016: South-East Asia \& Australia, 1-48.

Buzan, Waever, \& Wilde (1998). Security A New Framework for Analysis, hal.11, 198.

Buzan, B. (1998, Juni). The Southeast Asian Security Complex. Contemporary Southeast Asia, 116.

Buzan \& Waefer (2003). Regions and Power : The Structure of International Security. (Oxford:Cambridge University Press, 2003), hal. 44, 47, 61.

Capie, D. (2004). Between a hegemon and a hard place: the "war on 
terror' and Southeast Asian-US relations. The Pacific Review, 17:2, 223-248.

Croissant. A. \& Barlow, D. (2007). Following the Money Trail: Terrorist Financing and Government Responses in Southeast Asia. Studies in Conflict \& Terrorism. 30:2, 131156.

Desker, B. (2003): Islam in Southeast Asia: The Challenge of Radical Interpretations. Cambridge Review of International Affairs, 16:3, 415-428.

Emmers, Ralf (2009) Comprehensive security and resilience in Southeast Asia: ASEAN's approach to terrorism. The Pacific Review, Vol. 22 No. 2 May 2009: 159-177.

Hayes, B. (2012). Counter-Terrorism, Policy Laundering, and the FATF: Legalizing Surveillance, Regulating Civil Society. International Journal of Not-forProfit Law, 2012:11.

IPAC (2019). Protecting The SuluSulawesi Seas From Abu Sayyaf Attacks, 1

Jones \& Smith (2002). The perils of hyper-vigilance: the war on terrorism and the surveillance state in South-East Asia. Intelligence and National Security, 17:4, 31-54.

Kertopati, S (2013, Januari 17). Pemberantasan Pendanaan Terorisme. Dipetik Maret 20, 2019, dari Kompas: https://nasional.kompas.com/read/ 2013/01/17/03111848/Pemberanta san.Pendanaan.Terorisme

Kiser, S. (2005). Financing Terror: An Analysis and Simulation for
Affecting Al Qaeda's Financial Infrastructure. Rand, 4-5.

Kivimaki, T. (2007, Maret 1). Can development and democratization address the root causes of terrorism in Southeast Asia?. The Pacific Review, Vol. 20: 49-73.

Mustapha, J. (2011) Threat Construction in the Bush Administration's Post-9/11 Foreign Policy: (Critical) Security Implications for Southeast Asia. The Pacific Review, 24:4, 487504.

Perrin, A. (2002, November 25). Thailand's Terror: Has Thailand's Muslim-dominated south served as a training and staging base for jihadi terrorists?, 160

Renwick, Neil (2007) Southeast Asia and the global 'war on terror' discourse. Cambridge Review of International Affairs, 20:2, 249265.

Singh, D. (2009) Responses to Terrorism in Southeast Asia. Journal of Policing, Intelligence and Counter Terrorism, 4:1, 1528.

Sundararaman, Sankari (2002) South-east Asian perceptions on the 'war against terrorism', Strategic Analysis, 26:3, 394-405.

Swanström, Niklas \& Björnehed, Emma (2004) Conflict Resolution of Terrorists Conflicts in Southeast Asia. Terrorism and Political Violence, 16:2, 328-349.

The Egmont Group (2004, September). Information Paper on Finacial Intelligence Units and The Egmont Group, 2.

US Department of State Publication (2017, Juli). Country Reports on Terrorism 2016, 47-67. 